\title{
Supplementary Description of Aculus scutellariae (Canestrini et Massalongo, 1895) (Acariformes: Eriophyoidea) from Hungary
}

\author{
G. RIPKA \\ National Food Chain Safety Office, Directorate of Plant Protection, Soil Conservation \\ and Agri-environment, Department of Pest Management Development and Coordination, \\ H-1118 Budapest, Budaörsi út 141-145, Hungary
}

(Received: 7 November 2017; accepted: 24 November 2017)

\begin{abstract}
Female of Aculus scutellariae (Canestrini et Massalongo, 1895) is redescribed, male and nymph are described and illustrated. It was collected from Scutellaria hastifolia L. (Fam. Lamiaceae) in Hungary.
\end{abstract}

Keywords: Eriophyidae, Aculus scutellariae, spear-leaved skullcap, Hungary.

On skullcap species (Scutellaria spp.) only one eriophyoid mite is known, Aculus scutellariae (Canestrini et Massalongo, 1895) (Amrine and Stasny, 1994, 1996; Davis et al., 1982). It is known from Austria, Finland, France, Italy, Hungary, Russia and the former Yugoslavia (Farkas, 1966; de Lillo, 2012; Roivainen, 1951). The current systematic position of the species is not certain. Davis et al. (1982) listed it as Vasates scutellariae (Canestrini and Massalongo, 1895), while Amrine and Stasny (1994) mentioned it as Aculus? scutellariae (Canestrini and Massalongo). The original description of Aculus scutellariae, as Phyllocoptes scutellariae, is incomplete and brief (without figures, lacking information on the measurements of morphological structures, leg setation, morphology of gnathosoma, female coxigenital region, etc.) (Canestrini and Massalongo, 1895). Roivainen (1951) placed 9 Phyllocoptes species in the genus Vasates. One of them is Vasates scutellariae (Can. et Mass.) Roiv. n. comb. He gave some morphometric data of it but without illustrations. Farkas (1966) also mentioned the species as Vasates scutellariae, gave similar morphometric data, and illustrated only the prodorsal shield. No information is known on male and nymph. The main goal of my work is to present a detailed description and illustration of female, male and nymph of A. scutellariae. In Hungary the genus Aculus is represented by 44 species which were recorded from the host plants of 20 dicotyledonous plant families (Ripka, 2007).

\footnotetext{
* Corresponding author; e-mail: RipkaG@nebih.gov.hu
} 


\section{Materials and Methods}

The eriophyoid mite fauna of spear-leaved skullcap, Scutellaria hastifolia L., was studied from plant samples collected in Vászoly, Veszprém county (West Hungary), at the end of May 2017. The plant material (including leaves, petioles, stems, buds and flowers) was collected in plastic bags, then returned to the laboratory and examined under a stereo dissecting microscope (Zeiss Stemi 2000-C). After clearing the eriophyoid mites in lactic acid they were mounted in Keifer's F-medium with sorbitol on microscope slides (Keifer, 1975). Specimens were examined with the aid of a research phase contrast compound microscope (Nikon Eclipse E600) equipped with a drawing tube (Nikon Y-IDT). External morphology (e.g. prodorsal shield, gnathosoma, coxigenital region of female, genital region of male) of Aculus scutellariae was also investigated with the aid of scanning electron microscopy (SEM) (Zeiss EVO 40 XVP) at the Institute of Materials and Environmental Chemistry, Research Centre for Natural Sciences, Hungarian Academy of Sciences, Budapest. Live mites were collected individually with a fine entomological needle from fresh plant parts under a stereomicroscope and placed directly on the SEM holder without fixation, dehydration and coating.

The generic classification was made according to Amrine et al. (2003) together with further updating. The terminology and setal notation used in the morphological descriptions follow Lindquist (1996). The number of measured specimens (n) is given in parentheses following the body length. All measurements of mites were made according to Amrine and Manson (1996) and are given in micrometers. Measurements and means are rounded off to the nearest integer. All measurements, unless specified otherwise, are lengths. For females the mean and the ranges are given. For male and immature stage, only the data of one specimen are given.

The scientific name of host plant is used according to Király (2009) and Király et al. (2011).

\section{TAXONOMY \\ Superfamily ERIOPHYOIDEA Nalepa Family ERIOPHYIDAE Nalepa Subfamily PHYLLOCOPTINAE Nalepa Tribe ANTHOCOPTINI Amrine and Stasny Genus Aculus Keifer}

\section{Aculus scutellariae (Canestrini et Massalongo, 1895)}

(Figs 1-7)

Diagnosis - Body fusiform. Prodorsal shield pattern composed of two, incomplete, faint and sinuous admedian lines; two, complete submedian lines; median line absent; irregular and faint dashes; with a short anterior lobe; empodium entire, 4-rayed; coxister- 
nae I forming a median sternal line, coxisternae I with many small granules, coxisternae II with less numerous small granules; opisthosoma with microtuberculate ventral semiannuli, dorsal semiannuli with faint microtubercles; female genital coverflap with 9-10 longitudinal ridges. Caudal lobes normal in size and shape.

Female - Body yellowish white, fusiform, 183 (162-197, n=8), 65 (62-69) wide, 67 (65-70) thick. Gnathosoma 22 (15-27), projecting obliquely downwards; chelicerae 17 (11-20), dorsal palp genual setae $d 5$ (3-7), unbranched, pedipalp coxal setae ep 2 (2-3). Prodorsal shield 37 (32-40), 52 (47-55) wide, semicircular; with a short 2 (1-2) frontal lobe; shield pattern composed of two incomplete, faint and sinuous admedian lines, diverging to rear; two complete submedian lines join the admenians at anterior $1 / 4$; irregular and faint dashes; median line absent. Ornamentation of prodorsal shield is considerably variable, e.g. number, size and position of lines, granules, and admedians broken on some specimens. Tubercles of scapular setae $s c$ on rear shield margin, 27 (25-30) apart, diverging, scapular setae sc 39 (33-45), directed rearwards. Oval granules situated in lateral rows on epicoxal areas, i.e. laterally between shield margin and dorsal coxae of legs I and II (sensu Chetverikov and Craemer, 2015).

Legs with all usual segments and setae present. Leg I (foreleg) 37 (34-38), femur 11 (10-12), basiventral femoral seta $b v 11$ (10-12), genu 5 (5-6), antaxial genual seta $l$ " 30 (28-31), tibia 11 (10-12), short paraxial tibial seta $l^{\prime}$ located at $1 / 4$ (1/5-1/4) from dorsal base, 5 (4-6), very thin, tarsus 7 (7-8), unguinal tarsal setae $u$ ' 3 , solenidion $\omega 8$ (7-8), distally blunt, slightly curved, empodium simple, bilaterally symmetrical, 5 (5-6), 4-rayed, each ray of three basal pairs with additional secondary branches.

Leg II (rear leg) 34 (32-35), femur 12 (10-12), basiventral femoral seta $b v 11$ (10$12)$, genu 5 (4-5), antaxial genual seta $l$ " 9 (9-10) very thin, tibia 8 (7-10), tarsus 7 (6-7), unguinal tarsal setae $u$ ' 3 , solenidion $\omega 8$ (7-9), distally blunt, slightly curved, empodium simple, bilaterally symmetrical, 6 (5-6), 4-rayed, each ray of three basal pairs with additional secondary branches. Small spinules distally on femora, genua and tibiae on both leg pairs.

Coxigenital area with 4-5 faint microtuberculate semiannuli. Coxisternae I with many small granules, coxisternae II with less numerous small granules; anterior seta on coxisternum I, $1 b 5$ (4-5), tubercles setae $1 b 11$ (10-12) apart, proximal seta on coxisternum I, la 14 (12-17), tubercles $1 a 10$ (9-10) apart, proximal seta on coxisternum II, seta $2 a 42$ (37-45), tubercles $2 a 23$ (22-25) apart. Subcapitular plate somewhat wide shield shape, with granules. Prosternal apodeme 11 (10-12).

Opisthosoma with 36 (32-42) dorsal, 63 (62-65) microtuberculate ventral semiannuli. Dorsal semiannuli with very faint microtubercles. Last 7-10 annuli with linear microtubercles on ventral side. Opisthosomal seta $c 219$ (14-25), on annulus 10 (9-11); opisthosomal setae $d 50$ (45-55), on annulus 24 (23-25); opisthosomal setae $e 21$ (19-27), on annulus 39 (37-41); opisthosomal setae $f 24$ (22-25), on annulus 58 (57-60), or 5 (5) from the rear. Opisthosomal seta $h 256$ (52-61), very thin at apex, opisthosomal seta $h 14$ (3-5). Caudal lobes normal.

Genital plate 17 (15-18), 22 (20-25) wide. Female genital coverflap with 2-3 transverse lines basally and 9-10 longitudinal ridges; coxisternal III setae $3 a 16(15-17)$ apart, 18 (16-20), very thin. The transverse lines are broken on some specimens. (Figs 1, 2, 3, 4, 5). 


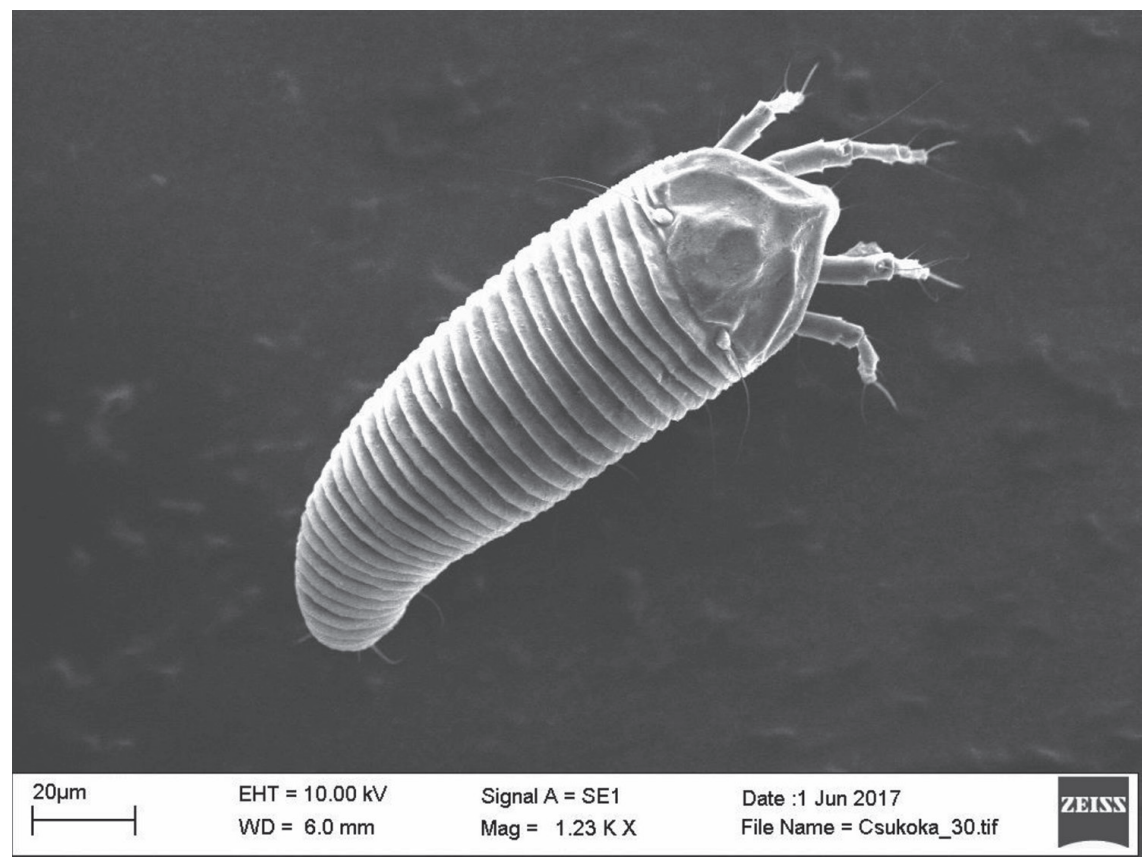

Fig. 1. SEM micrograph of Aculus scutellariae, dorsal view of probably a female

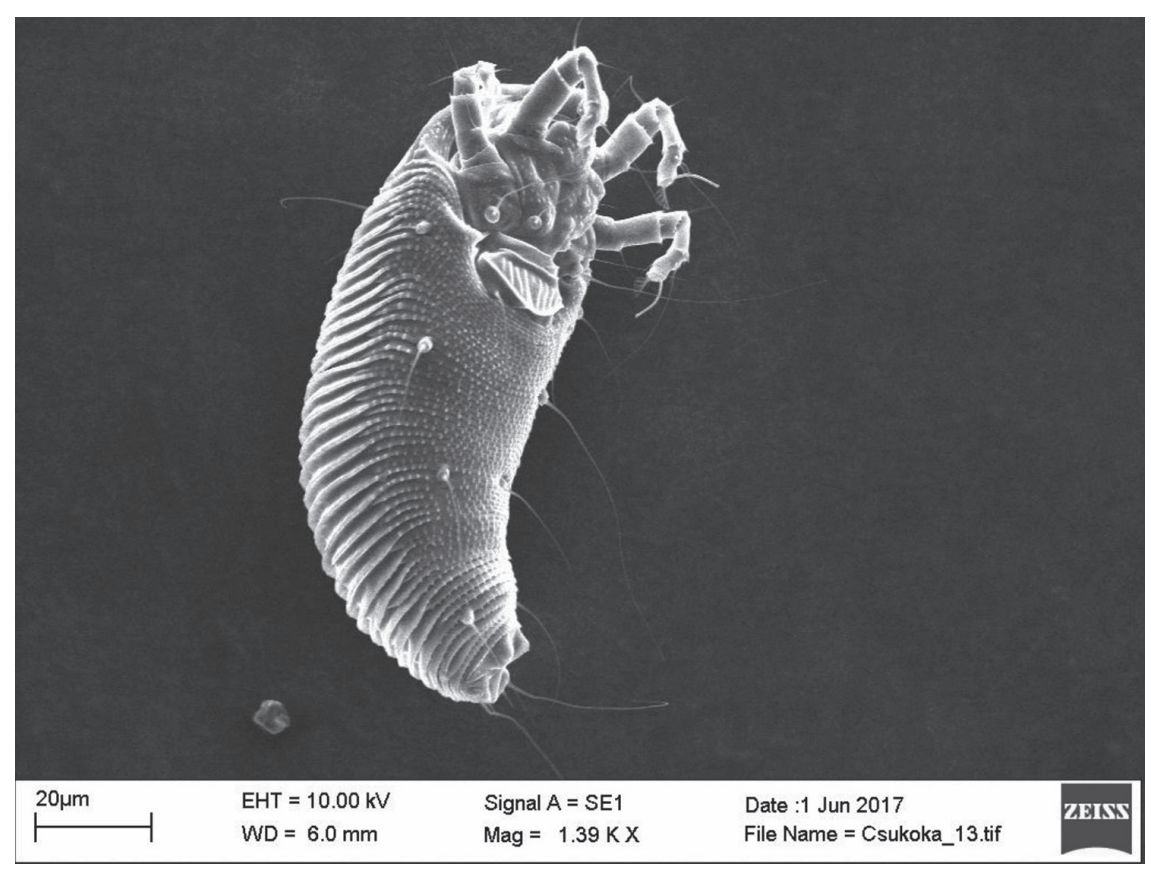

Fig. 2. SEM micrograph of Aculus scutellariae, ventrolateral view of female 


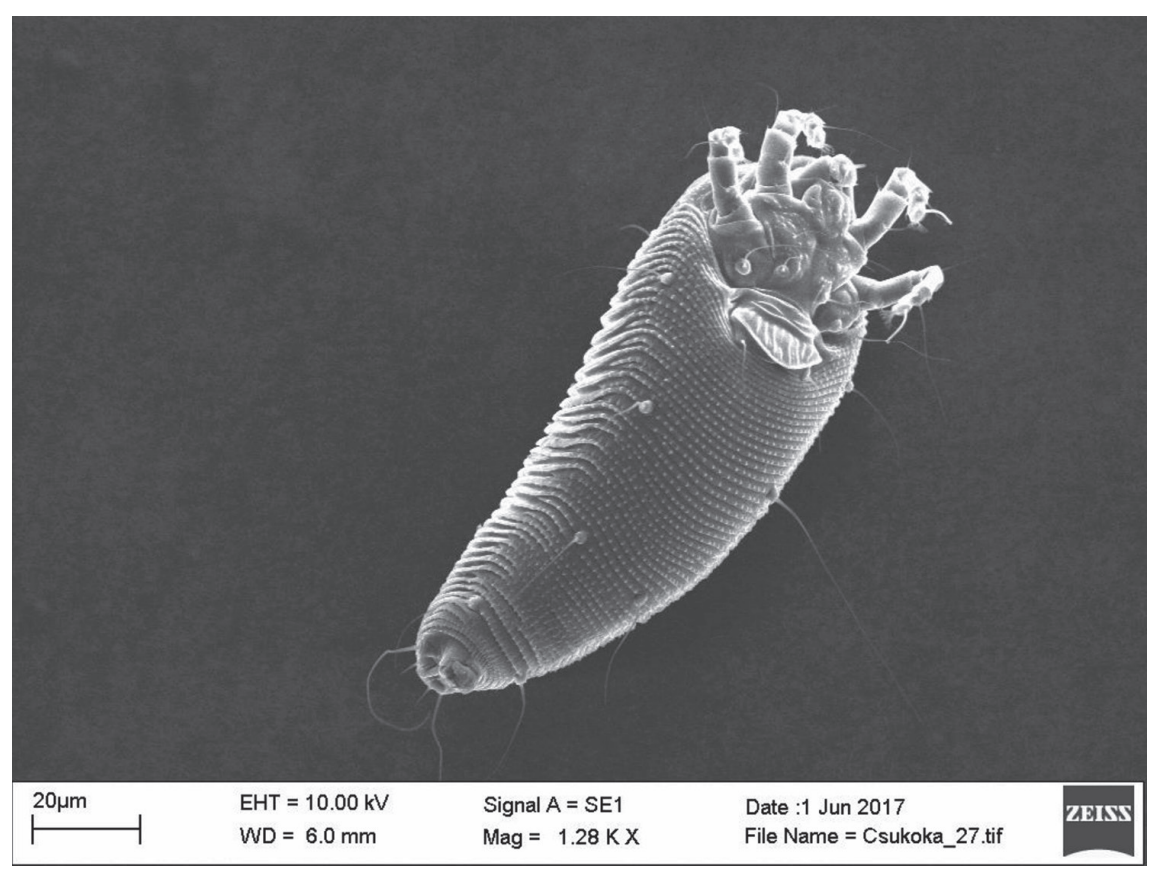

Fig. 3. SEM micrograph of Aculus scutellariae, ventrolateral view of female

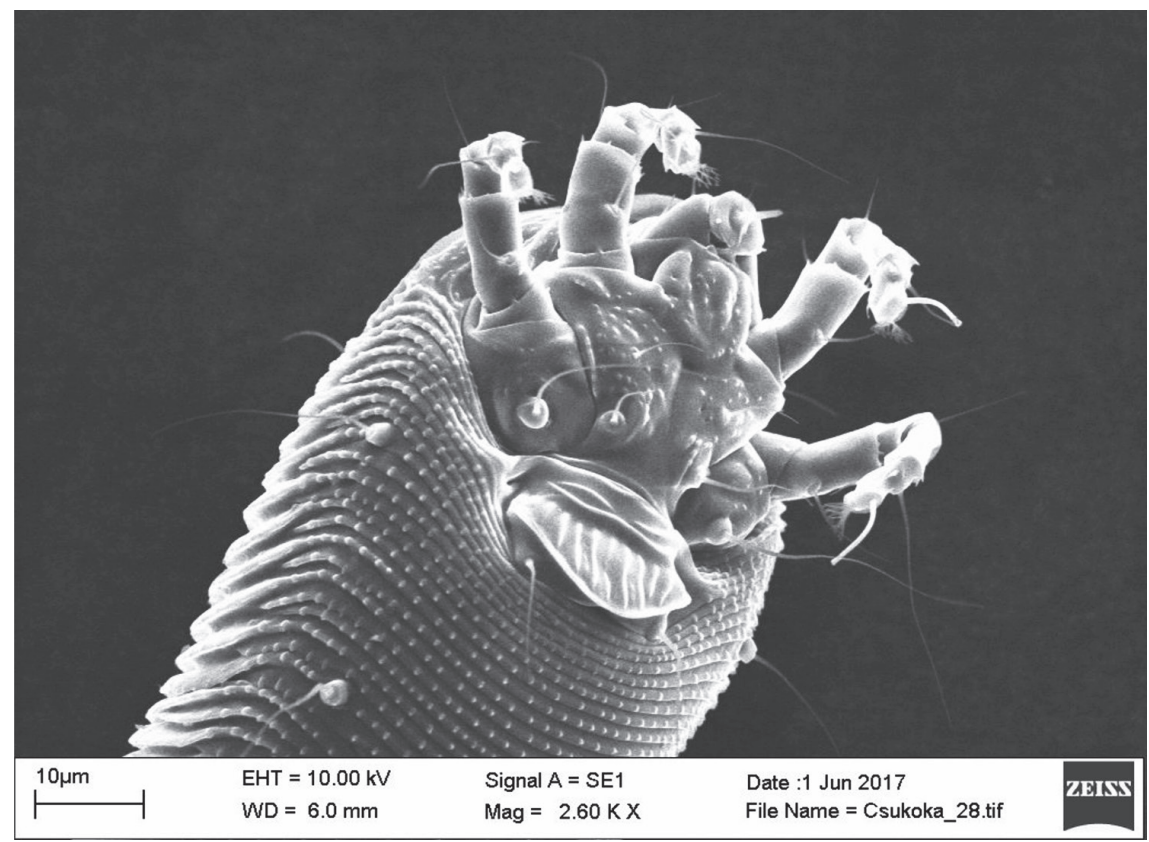

Fig. 4. SEM micrograph of Aculus scutellariae, ventral anterior region of female: gnathosoma and coxigenital region 
MALE - Similar to female, $154(\mathrm{n}=1), 53$ thick. Gnathosoma 22, projecting obliquely downwards; chelicerae 17 , dorsal palp genual setae $d 4$, unbranched, pedipalp coxal setae ep 1. Prodorsal shield 32, 40 wide, semicircular, with a short frontal lobe 1 , shape and ornamentation similar to female. Tubercles of scapular setae $s c$ on rear shield margin, setae sc 29, directed to the rear. Fine granules laterally in rows between shield margin and dorsal coxae of legs I and II. Legs with all usual segments and setae present. Leg I 28, femur 7, genu 4, antaxial genual setae l' 27, tibia 7, paraxial tibial setae $l$ ' located at $1 / 4$ from dorsal base, 3 , very fine, tarsus 5 , unguinal tarsal setae $u$ ' 3 , solenidion $\omega 7$, slightly curved, distally blunt, empodium simple, bilaterally symmetrical, 5 , with 4 paired rays. Leg II 25 , femur 7, basiventral femoral setae $b v 6$, very fine, genu 4 , antaxial genual setae l' 6, very fine, tibia 5, tarsus 5, unguinal tarsal setae $u$ ' 3 , solenidion $\omega 8$, slightly curved, distally blunt, empodium simple, bilaterally symmetrical, 5 , with 4 paired rays. Minute spinules distally on femora, genua and tibiae on both leg pairs. Coxigenital area with 4 faint microtuberculate semiannuli. Coxisternum I with many small granules, coxisternum II with less numerous granules; anterolateral setae on coxisternum I, setae $1 b$ 4 , proximal setae on coxisternum I, setae $1 a 10$, proximal setae on coxisternum II, setae $2 a 33$, very fine. Subcapitular plate somewhat wide shield shape, with granules. Prosternal apodeme 11. Opisthosoma with 29 dorsal, 55 ventral semiannuli. Dorsal semiannuli with very faint microtubercles, microtuberculate ventral semiannuli. Minute, round and pointed microtubercles set on rear annular margin, except for 7 ventral semiannuli of anal lobes, which are elongate and linear. Caudal lobe normal in size and shape. Setae $c 211$, on annulus 9; setae $d 42$, on annulus 19; setae $e 18$, on annulus 33; setae $f 22$, on annulus 50 , or 5 from rear. Setae $h 2$ 51; setae $h 13$. Genitalia 15, 16 wide, with 2-3 transverse lines basally, and with many minute granules; setae $3 a$ 12. (Fig. 6).

NYMPH - White, vermiform, $151(\mathrm{n}=1), 50$ wide. Gnathosoma 12, chelicerae 8. Prodorsal shield 30, 40 wide, semicircular. Tubercles of scapular setae $s c$ on rear shield margin, 24 apart, setae $s c$ 17, pointing rear. Leg I 25, femur 6, basiventral femoral seta bv 4, genu 2, antaxial genual setae $l$ ' 17 , tibia 5, paraxial tibial setae $l$ ' located at $1 / 3$ from dorsal base, 2 , very fine, tarsus 5 , solenidion $\omega 5$, slightly curved, distally blunt, empodium simple, bilaterally symmetrical, 4, with 4 paired rays. Leg II 22, femur 6, basiventral femoral setae $b v 5$, very fine, genu 2, antaxial genual setae $l$ ' 5 , very fine, tibia 4 , tarsus 4 , solenidion $\omega 6$, slightly curved, distally blunt, empodium simple, bilaterally symmetrical, 3 , with 4 paired rays. Setae $1 b 5$, tubercles setae $1 b 11$ apart, setae $1 a 10$, tubercles setae 1 a 8 apart, setae $2 a$ 24, tubercles setae $2 a 22$ apart. Opisthosoma with 44 dorsal, 46 ventral semiannuli. Dorsal and ventral semiannuli with minute microtubercles like dots. Setae $c 213$, on annulus 10, 42 apart; setae $d 37$, on annulus 19, 30 apart; setae $e$ 15, on annulus 28, 15 apart; setae $f$ 17, on annulus 41, or 5 from rear, 17 apart. Setae $h 2$ 50, 10 apart; setae $h 1$ 3, 5 apart. Setae $3 a 10,12$ apart. (Fig. 7).

Host plant - Spear-leaved skullcap, Scutellaria hastifolia L. (Fam. Lamiaceae). A sporadic perennial plant living in different plant associations of Hungary.

Relationship to the host - This mite caused distinct leaf deformation especially on the shoot tips. The young leaves rolled upward and twisted. The mite was found in all stages of development on stems, underside and upper side of the leaves of the host. 


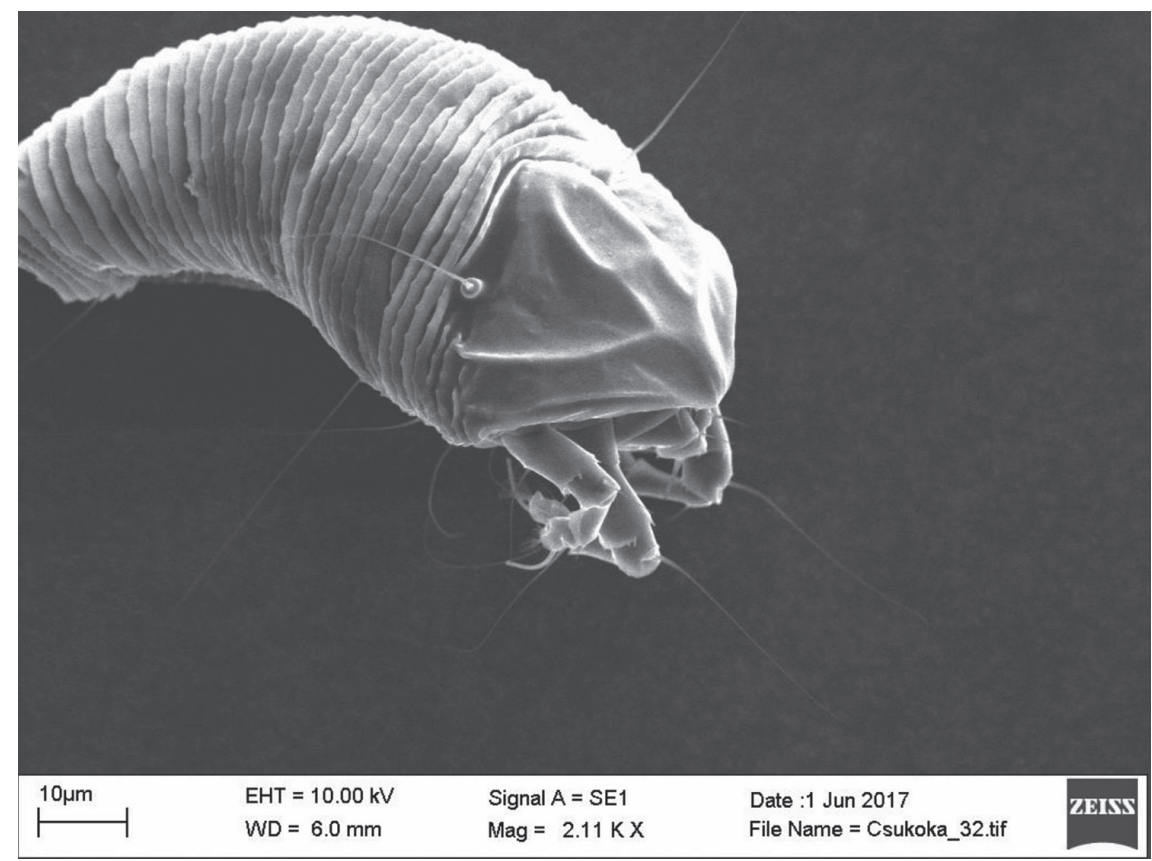

Fig. 5. SEM micrograph of Aculus scutellariae dorsolateral view of probably a female

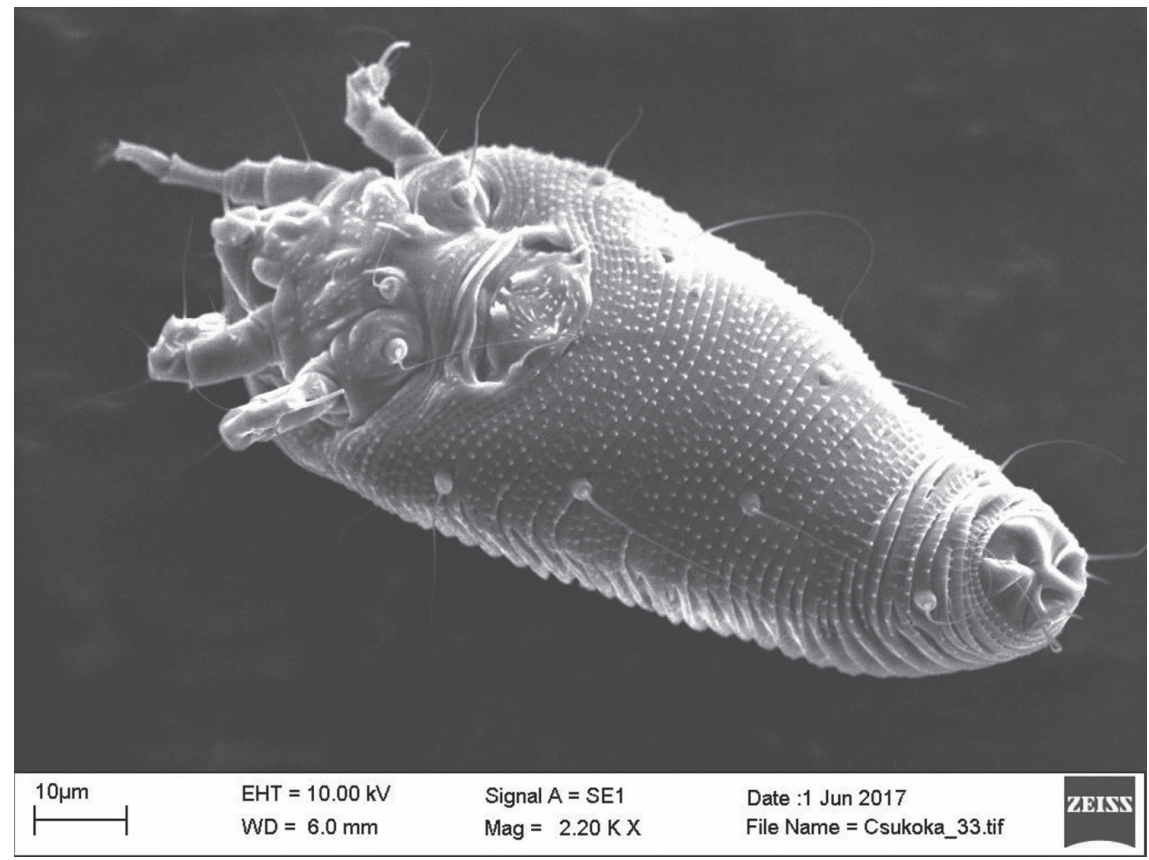

Fig. 6. SEM micrograph of Aculus scutellariae, ventrolateral view of male 


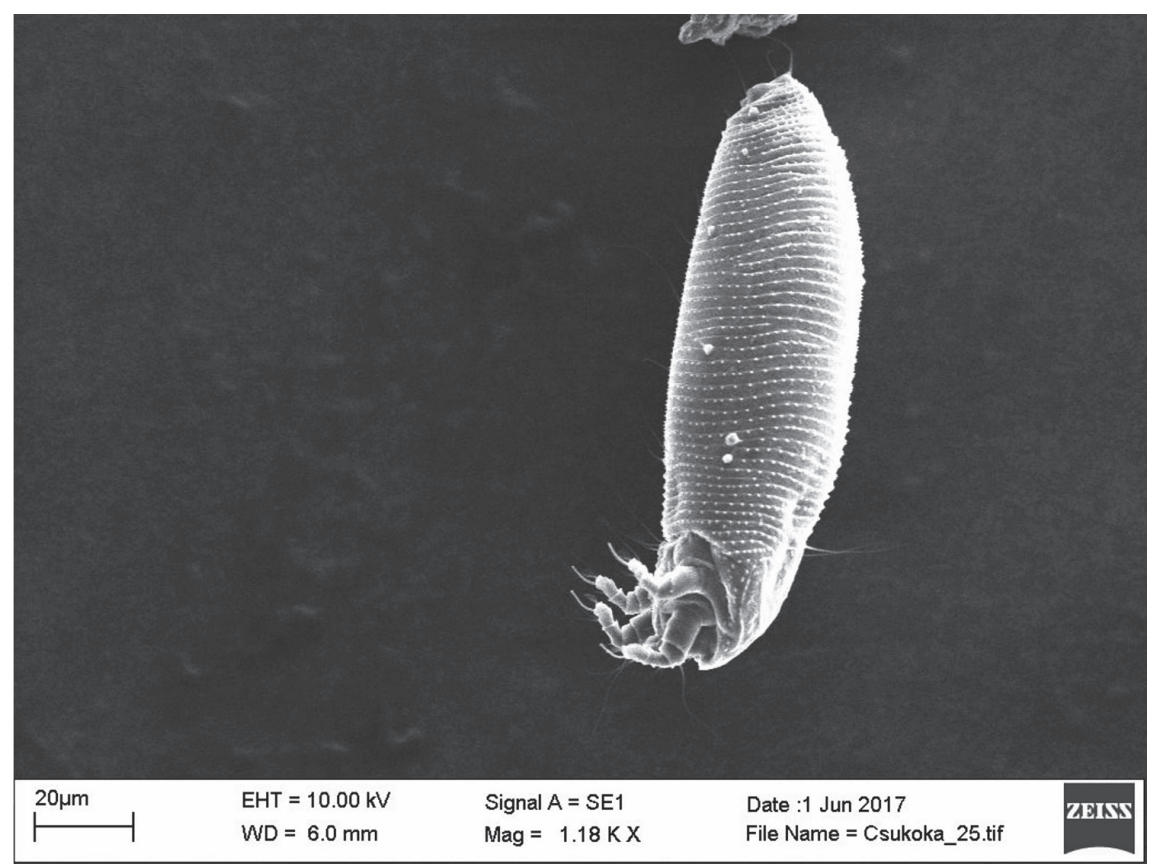

Fig. 7. SEM micrograph of Aculus scutellariae, lateral view of nymph

Type locality - Vászoly, Veszprém county (West Hungary), in seminatural habitat, close to the periphery of xerophile oak woods (Quercus petraeae-cerris forest) on magnesian limestone (Borhidi, 2003), 186 m elev.; $46^{\circ} 932063$ N, $17^{\circ} 774416$ E. (46 $55^{\prime} 55.4^{\prime \prime}$ N, 17²6'27.9" E.)

Material examined - the redescribed female and described male and nymph circled with black ink among 8 females on one slide, 28 May 2017, slide \# 1413a, coll. G. Ripka. Other specimens were collected - 1 slide (\# 1413b) prepared from material collected by G. Ripka in the same locality and time, containing 1 female and 3 nymphs from stems, underside and upper side of the leaves of the same host are in the author's collection and deposited in the National Food Chain Safety Office, Directorate of Plant Protection, Soil Conservation and Agri-environment, Department of Pest Management Development and Coordination, Budapest, Hungary.

\section{Discussion}

The previous descriptions are different. In the original description, the prodorsal shield is smooth, the ca 40 annuli are smooth (Canestrini and Massalongo, 1895). Roivainen (1951) gave some additional morphometric data, e.g. the prodorsal shield is 40 long, ellipsoidal and smooth, length of setae sc is 45-57, opisthosoma with 35-38 smooth dorsal annuli plus 5 caudal annuli. According to Farkas (1966), the prodorsal shield is 39 
long, shield pattern is faint with two incomplete admedian lines which did not reach the anterior margin of the shield, and one line on each side of the shield margin ( \pm submedian lines), length of setae $s c$ is 38, opisthosoma with $c a 40$ smooth dorsal annuli.

The male and nymph of the species is herein described.

\section{Acknowledgements}

Thanks are expressed to Dr. László Szabó (Institute of Materials and Environmental Chemistry, Research Centre for Natural Sciences, Hungarian Academy of Sciences, Budapest, Hungary) for his help in preparing the SEM micrographs and Mr Ede Böszörményi (National Food Chain Safety Office, Budapest) for linguistic revision of an initial draft of the manuscript.

\section{Literature}

Amrine, J. W. Jr. and Manson, D. C. M. (1996): Preparation, mounting and descriptive study of eriophyoid mites. In: E. E. Lindquist, M. W. Sabelis and J. Bruin (eds): Eriophyoid Mites - Their Biology, Natural Enemies and Control. Elsevier, World Crop Pests, 6. Amsterdam, Lausanne, New York, Oxford, Shannon, Tokyo, pp. 383-396.

Amrine, J. W. Jr. and Stasny, T. A. (1994): Catalog of the Eriophyoidea (Acarina: Prostigmata) of the World. Indira Publishing House, West Bloomfield, pp. ix + 798 [USA]

Amrine, J. W. Jr. and Stasny, T. A. (1996): Corrections to the catalog of the Eriophyoidea (Acarina: Prostigmata) of the World. Int. J. Acarology 22, 295-304.

Amrine, J. W. Jr., Stasny, T. A. H. and Flechtmann, C. H. W. (2003): Revised Keys to World Genera of Eriophyoidea (Acari: Prostigmata). Indira Publishing House, West Bloomfield, iv + 244 p. [USA]

Borhidi, A. (2003): Magyarország növénytársulásai. [Plant Communities of Hungary]. Akadémiai Kiadó, Budapest, $610 \mathrm{p}$.

Canestrini, G. and Massalongo, C. (1895): Su due nuove specie di fitoptidi. Bolletino della Societá Veneto-Trentina di Scienze Naturali 6, 20-21.

Chetverikov, P. E. and Craemer, C. (2015): Gnathosomal interlocking apparatus and remarks on functional morphology of frontal lobes of eriophyoid mites (Acariformes, Eriophyoidea). Exp. Appl. Acarology, 66, 187-202. http://dx.doi.org/10.1007/s10493-015-9906-3

Davis, R., Flechtmann, C. H. W., Boczek, J. H. and Barké, H. E. (1982): Catalogue of Eriophyid Mites (Acari: Eriophyoidea). Warsaw Agricultural University Press, Warsaw, $254 \mathrm{p}$.

de Lillo, E. (2012): Fauna Europaea: Eriophyoidea. In: W. Ł. Magowski (ed.): Fauna Europaea: Acari: Acariformes. Fauna Europaea version. 2.4. http://www.faunaeur.org (accessed 7 June 2017)

Farkas, H. (1966): Gubacsatkák - Eriophyidae. In: Fauna Hungariae: [Gall Mites - Eriophyidae. In: Animals of Hungary]. Akadémiai Kiadó, Budapest, 81, pp. 1-164.

Keifer, H. H. (1975): Eriophyoidea Nalepa. In: L. R. Jeppson, H. H. Keifer and E. W. Baker (eds): Mites Injurious to Economic Plants. University of California Press, Berkeley, Los Angeles, London. pp. 327-533.

Király, G. (ed.) (2009): Új magyar füvészkönyv. Magyarország hajtásos növényei. Határozókulcsok. [New Hungarian Herbal. The Vascular Plants of Hungary. Identification Key.]. Aggteleki Nemzeti Park Igazgatóság, Jósvafö, 616 p.

Király, G., Virók, V. and Molnár, V. A. (eds) (2011): Új magyar füvészkönyv. Magyarország hajtásos növényei. Ábrák. [New Hungarian Herbal. The Vascular Plants of Hungary. Illustrations.]. Aggteleki Nemzeti Park Igazgatóság, Jósvafö, 676 p.

Lindquist, E. E. (1996): External anatomy and notation of structures. In: E. E. Lindquist, M. W. Sabelis and J. Bruin (eds.): Eriophyoid Mites - their Biology, Natural Enemies and Control. World Crop Pests, 6. Elsevier Scientific Publishing, Amsterdam, The Netherlands, pp. 3-31. 
Ripka, G. (2007): Checklist of the eriophyoid mite fauna of Hungary (Acari: Prostigmata: Eriophyoidea). Acta Phytopathol. et Entomol. Hun. 42, 59-142.

Roivainen, H. (1951): Contributions to the knowledge of Eriophyidae of Finland. Acta Entomol. Fennica 8, 1-72. 